\title{
Using DPSIR Framework to Determine Secondary School Students' Conception of Ecological Concepts in the Context of a Wetland Ecosystem
}

\author{
Kabelo Damacina Tlhakola1*, Tšepo Mokuku¹
}

1 National University of Lesotho, LESOTHO

*Corresponding Author: mkd20093713@gmail.com, tmmokuku@yahoo.com

Citation: Tlhakola, K. D., \& Mokuku, T. (2021). Using DPSIR framework to determine secondary school students' conception of ecological concepts in the context of a wetland ecosystem. Interdisciplinary Journal of Environmental and Science Education, 17(4), e2252. https://doi.org/10.21601/ijese/11021

\begin{tabular}{ll}
\hline ARTICLE INFO & ABSTRACT \\
\hline Received: & $\begin{array}{l}\text { This study investigated the secondary school students' conception of ecological concepts, based on } \\
\text { 21 March 2021 } \\
\text { wetland ecosystem. The guiding question was 'What is grade 11 students' conception of ecological } \\
\text { concepts in association with Koro-Koro wetland?'. Thirty-one Grade 11 students were assessed for } \\
\text { their understanding, within the Driving-Pressure-State-Impacts-Response (DPSIR) framework. A }\end{array}$ \\
Accepted: & $\begin{array}{l}\text { questionnaire was administered to establish the students' conceptions. The findings revealed that } \\
\text { 10 May 2021 } \\
\text { students' understanding of their local wetland was relatively better in wetland fauna, and limited in } \\
\text { relation to plant diversity, ecosystem energy flow and conceptualization of an ecosystem. Many } \\
\text { students could not relate what they learnt in class to their local environment. It is recommended that } \\
\text { future studies be directed towards investigating teaching strategies that can effectively enhance } \\
\text { students' scientific understanding of local wetlands. }\end{array}$
\end{tabular}

Keywords: wetlands ecosystem, ecological concepts, DPSIR model, secondary school students

\section{INTRODUCTION}

Now, more than ever, environmental dilemmas, such as wetland degradation, have made it imperative that students become knowledgeable about the nature of an ecosystem (Minshew et al., 2017), which is a central concept in ecology (Yorek, Sahin, Ugulu, \& Dogan, 2010). School science teaching in Lesotho occurs in the context of escalating environmental degradation, as catchments are subjected to poor land management practices and associated destruction of biodiversity and water sources (Ministry of Forestry, Range and Soil Conservation, 2015). However, a case study in Lesotho that assessed secondary school students' knowledge of environmental problems showed that they were generally not aware of their local environmental problems (Molapo et al., 2014). When the same students were asked to give examples of environmental problems in the country, they mostly mentioned socio-economic, rather than biophysical problems, even though they were taught about the latter in Biology (Molapo et al., 2014). As a member of United Nations Educational, Scientific and Cultural Organization (UNESCO), Lesotho is committed to observing a global call to use education in promoting the understanding and alleviation of environmental problems (EP) (UNESCO \& UNFCCC, 2016). In addition, the Ramsar Convention, also known as Convention on Wetlands of International Importance, signed by Lesotho on the 1st November 2004, provides an impetus to the conservation and sustainable utilization of wetlands. Nonetheless, the bearing of this long standing agreement on school curriculum has not received much attention and exploration.

The specific objectives stated in the Lesotho Junior Secondary (JC) science syllabus (NCDC, 2008), reflect strong congruence with Ecological Literacy (EL), with its emphasis on relations between ecology, economy, and social systems (Rabiatual \& Norizan, 2013). EL has been defined as "... an ability to "read"

Copyright (C) 2021 by Author/s and Licensed by Veritas Publications Ltd., UK. This is an open access article distributed under the Creative Commons Attribution License which permits unrestricted use, distribution, and reproduction in any medium, provided the original work is properly cited. 
the many interwoven relationships (i.e., biotic and abiotic) that are built of the Earth" (Mitchell, 2009, p.6). The study aimed to determine Secondary School Students' (SSS) understanding of key biophysical ecological concept in the context of a wetland ecosystem, using 'Drivers-pressure-state-impactresponse' (DPSIR) as a theoretical framework (Fortuin et al., 2011). The study was guided by the following research questions: What is grade 11 students' understanding of the ecological concepts in association with Koro-Koro Wetland?

\section{LITERATURE REVIEW}

The wetland ecosystem content used to determine students' conception of ecological concepts is based on the following concepts: food chains and webs and energy flow, decomposition, biodiversity and wetland ecosystem. Below is a discussion of the students' understanding of these concepts from the literature:

\section{Food Chains and Webs and Energy Flow}

In Lesotho context, Examination Council of Lesotho Examiners' report of 2013 shows that many students could not construct a food chain and did not understand the relationships of organisms as energy flow (ECOL, 2017). When assessing Grade 8 students' conceptions of energy flow through ecosystem, Arkwright (2014) found that they were able to identify the producer from the food web, but many of them thought that producers got food from other substances such as the sun, water, gravel and other organisms rather than relying on specific materials in the environment to make their own food. Other studies show that secondary students have a linear cause effect conception of the feeding relationships among living organisms, with the thought that 'strong eat weak' (Yorek et al., 2008; Minshew et al., 2017). For instance, their conception of cross relationships was that grasshoppers eat grass, rat eat grasshopper and hawk eat rats, and they rarely mentioned the possibility that a rat could eat grass or hawk could eat a grasshopper. In addition, the students could not conceptualize food chain as energy flow relationship but as predator-prey relationship (Minshew et al., 2017 and Strommen as cited by Yorek et al., 2010). They tend to believe that energy increases from the bottom to top in food pyramid, energy need increases from bottom to upper levels and that biomass increases from bottom to top in the food chain (Toman, 2018). In one study where students were able to state food chains, some could not realize that part of the plant, such as nectar consumed, count as producer which could affect their ability to reason about specific food chains and food web structures and disturbances in scientifically sound ways
(Rabiatul \& Norizan, 2013). Minshew et al. (2017) found that six out of 12 students could connect the sun and sunlight to producers while others only connected the sun to the plants without specifying the relationship; and a few others were able to mentioned rain (water) and carbon dioxide as materials needed by producers to make food.

\section{Decomposition}

Students have been found to struggle to explain how and why decomposition occurs (Arkwright, 2014). Cetin (2007) found that only a few of the Turkish and English seventh grade students were able to show that microorganisms like bacteria feed on organic molecules and rot them away. Many students, in the same study, had a misunderstanding that consumers, producers and soil are responsible for breaking complex molecules in an ecosystem in general; and that when plants die, carbon and water were released by evaporation (Cetin, 2007). A similar study shows secondary school students in Turkey interpreting an apple falling from the tree and disappearing as action of soil, rather than microorganism decomposition (Yorek et al., 2008, 2010). Another study (Schizas et al., 2013) found that middle school students relate decomposed matter to 'dead matter', 'dead animals', 'leaves' and 'bones' and not to products of organisms. In addition, students could not link decomposition to respiration, as they were unable to explain decomposition breaking organic matter to inorganic (Schizas et al., 2013).

\section{Biodiversity}

Regarding biodiversity, secondary school students can name limited animals for different ecosystems (Rabiatual \& Norizan, 2013; Yorek et al., 2008). For example, students can only name very common animals such as tiger and snakes in tropical forest, due to their limited experience of the ecosystem (Rabiatual \& Norizan, 2013). Concerning flora, a study reported that many secondary school learners had 'plant blindness' (Yorek et al., 2008); described as students' tendency to view plants as just the backdrops for animal life, and failure to see or notice the plants in the environment, and conception of life as associated with movement. However, Yardimci and Kilic (2010) found that Grade 8 students were more acquainted to plants than animals and preferred to live in a green and clean environment that consisted of mostly plants than animals, less industrialized and less affected by human. Students also tend to hold an anthropocentric view (Barrow, 1995) of the environment, in that they consider other living things, besides human beings, as less ecologically important but as just things to provide 
people with food, medicine and making honey (Yorek et al., 2008; Menzel \& Bögoholz, 2009).

Where ecosystem is involved, some learners have reflected an atomistic view that sees individual species; Yorek et al. (2010) for instance found that students focused on the animals and plants as elements of a forest, rather than interconnectedness of the forest ecosystem. In other contexts, they have been found to consider biodiversity as variety of plants and animals yet fail to connect biodiversity with the ecosystem; a few in the same study considered genetic diversity when describing biodiversity, and could link biodiversity with economy (Menzel \& Bögeholz, 2009).

\section{Wetland ecosystem}

Ramsar Convention on Wetlands provides a widely used definition of wetlands as: "areas of marsh, fen, peatland or water, whether natural or artificial, permanent or temporary, with water that is static or flowing, fresh, brackish or salt, including areas of marine water the depth of which at low tide does not exceed six metres" (Adekola \& Mitchell, 2011, p.50). There is some evidence that local wetlands are subjected to indiscriminate anthropogenic pressures, apparently due to limited knowledge about their ecological and hydrological significance (Mokuku \& Taylor, 2015; Thakola, 2017). Wetlands gave rise to the first modern global nature conservation convention and remain the only single group of ecosystems with their own international convention (Adekola \& Mitchell, 2011). Some authors refer to wetlands as the kidneys of the landscape because of their functions in the hydrological and chemical cycle or as biological supermarkets because of the extensive food web and rich biodiversity that they support (Barbier et al., 1997; Russi et al., 2013; TEEB 2010 as cited by Belle et al., 2018). Wetlands directly reduce disaster risks like soil erosion (National Environmental Secretariat, 2000; and Department of Environment, 2009) through the natural regulatory processes and indirectly by providing scope for local livelihoods and reducing poverty, which are documented causal factors of disaster. In Lesotho, wetlands play a major role in the supply of water locally and to the neighbouring countries in the region, yet wetlands content is not prominent in the school curricula. Yet, there is limited literature on wetland education in school curriculum in general (Shepardson at. Al., 2007). A few secondary school students consider wetlands as pretty places to visit for recreational activities, whereas some understand wetlands as habitation of animals and plants and sources of water, and some are not even aware of them (Weston et al., 2006). The present study is based on a wetland, with features of swamp, lake and river. Within this wetland is reflected a number of ecological concepts that students ought to have covered in the science syllabus under topics such as diversity of organisms, energy flow and food chains, and water issues.

\section{THEORETICAL FRAMEWORK}

The DPSIR framework was developed by European Environmental Agency (EEA) (Kristensen: 2004), as an integrated approach in reporting in EEA's State of Environment. According to Kristensen, (2004) and Fortuin et al. (2011) in DPSIR Framework, there is a chain of causal links starting with Drivers/Driving Forces (needs), Pressure (human activities resulting from needs in society), State (as a result of Pressure, how is the 'state' or quality of the environment), Impacts (changes in the state have environmental or economical 'impacts' on functioning of the ecosystem) and Response ('response' by society is as a result of undesired impact). Impact as a dimension of DPSIR, for instance, refers to changes in the physical, chemical or biological state of the environment and determines the quality of ecosystems and the welfare of human beings and therefore impact affects the functioning of the ecosystem (Kristensen, 2004). As such DPSIR is holistic and brings biophysical and social disciplines together (Levin et al., 2016). The relationship between ecology, economy and social is complex (Jordan et al., 2009; Levin et al., 2016: Minishew et al., 2017) and requires a framework that can make students easily understand the complex interdisciplinary nature of their environment. The present study, is only focused on the state dimension of DPSIR framework, in light its scientific nature, and congruence with the ecological topics that the students were taught. The Figure 1 below shows the visualized DPSIR Model:

Based on this framework, students were assessed on their knowledge in relation to each of the three domains and their relationship, the Drivers, Pressure and State.

\section{METHODOLOGY}

\section{Research Methods, Design, and Sampling}

This is a qualitative study that employed a case study design (Merriam, 1998; Cohen et al., 2017) so as to gain an in-depth understanding of the students' conceptions of the selected wetland ecological concepts. The case study school, and the study participants, Grade 11 students, were purposively selected, as this was the principal researcher's school, and the class she taught. The school is situated in a peri-urban area, close to the Koro-Koro wetland (KKW), on which the study was based. 


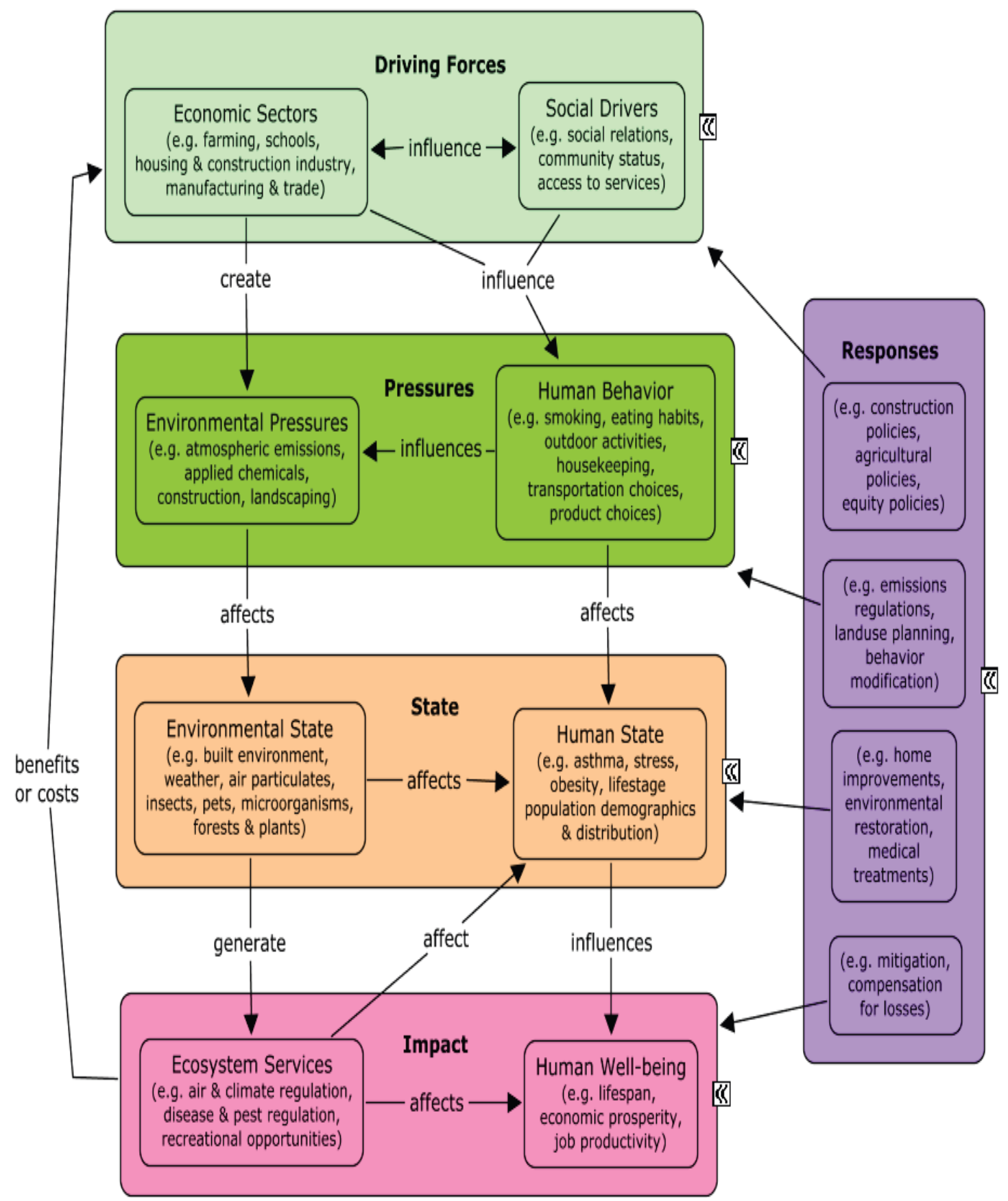

Source: Bradley and Yee (2015, p.4)

Figure 1. DPSIR Model

\section{Data Collection}

To answer the above-stated research question, three sources of data were employed: a questionnaire, with structured and semi-structured items, was administered and literature in relation KWW ecosystem was analysed for triangulation with the students' responses. The questionnaire was developed to establish what students already know (Yamaguchi \& Okada, 2018). The questionnaire was teacher-developed. The questionnaire items were developed based on key ecological concepts associated with a wetland ecosystem (See Table 1).
They were also constructed by reference to the JC syllabus. The items were further in framed in line with aspects of the DPSIR framework (driving forces, pressure, state, impacts and response), to assess students' Ecological Literacy in terms of DPSIR and ecological concepts that students were expected to be familiar with. The ecological concepts were largely associated with Koro-Koro wetland and were: Decomposition, sources of energy, biodiversity, energy flow, ecosystem service, food chains and webs, causes of environmental problems and solving environmental problems. 
Table 1. Organization of the students' questionnaire

\begin{tabular}{|c|c|c|c|}
\hline TEST ITEM & $\begin{array}{l}\text { DISPIR } \\
\text { DOMAIN } \\
\text { TESTED }\end{array}$ & $\begin{array}{l}\text { ECOLOGICAL CONCEPT } \\
\text { TESTED }\end{array}$ & QUESTION \\
\hline $\begin{array}{l}\text { Questions 2, 9, } \\
4 \text { and } 10\end{array}$ & State & Biodiversity & $\begin{array}{l}\text { 2c) The diagram below shows an animal that is found in the } \\
\text { lake at Koro-Koro Wetland. What is the name of this animal? } \\
\text { 9) Mention any FIVE birds that could be found in the } \\
\text { wetland. }\end{array}$ \\
\hline Questions 3. & State & Energy flow & $\begin{array}{l}\text { 3a) A wetland has different kinds of living things, which } \\
\text { depend on one another for energy. This life giving energy } \\
\text { flows in the wetland through food chains. An example of } \\
\text { food chain is given below. Name the producer in the food } \\
\text { chain. }\end{array}$ \\
\hline Question 2 & State & Importance of wetland & $\begin{array}{l}\text { 2a) Explain ONE importance of a wetland (or Mokhoabo in } \\
\text { Sesotho)? }\end{array}$ \\
\hline Question 2 & State & Ecosystem & $\begin{array}{l}\text { 2b) Is a wetland (Mokhoabo) an ecosystem? [Tick below] } \\
\text { Yes [ ] } \\
\text { No [ ].Explain your answer below: }\end{array}$ \\
\hline Question 5 & State & Importance of water & $\begin{array}{l}\text { 5b) Mention ONE importance of a wetland in the water } \\
\text { cycle. }\end{array}$ \\
\hline
\end{tabular}

The questionnaire was piloted with a different school from the sample school for validation with focus on content validity and construct validity (Honorene, 2017; Farquhar \& Michels, 2016; Olsen, 2004). The pilot study was qualitative and involved administration of the questionnaire to a class of 31 students. The students' responses were analyzed to determine whether their answers reflected a clear understanding of the questions, without language difficulties. The instrument was found to be reliable, as completing Grade 10 students were able to answer the questions.

The tool was administered to 31 Grade 11 students. Permission to carry out the research was obtained in advance from the school principal and the students themselves. The participants were also assured of the confidential handling of the data, and that the data would be used for the study and no other purposes.

\section{Data Analysis}

The students' responses were typed and organized in accordance with each question item. Then the responses were arranged into emerging themes in line with the research question (Mills et al., 2017; Merriam, 1998). Frequencies on emerging themes were determined. The questionnaire data were then triangulated (Cohen et al., 2007) with the transect walk and document analysis findings where appropriate. There were cases in the analysis of the data wherein students were requested to give more than one answer to a question, which resulted in responses or frequencies not corresponding to the number of students.

\section{FINDINGS}

The State of The KKW Ecosystem according to the Literature

The KKW ecosystem is a marshland with reed beds (National Environmental Secretariat, 2000). National Environmental Secretariat (2000) shows that KKW was one of a few wetlands that survived draining and soil erosion, meaning that KKW was thriving prior to the year 2000. However, it appears that KKW was impacted sometime after the National Environmental Secretariat (2000) was published. A preliminary study carried out earlier (Tlhakola, 2017) found that KKW was under anthropogenic pressure that had resulted in the following adverse impacts: Loss of rich biodiversity of birds that herders and the community used to enjoy and appreciate. Only a few birds were now reported to exist; this occurs in the context of 339 species of birds last recorded to exist in Lesotho about two decades ago (Ambrose, 1998). KKW is also subjected to pressure due to the community's reliance on it for ecological services such as water for domestic use and thatching reed.

Furthermore, authorities from Koro-Koro presenting at a seminar held on the $2^{\text {nd }}$ February 2004 on the celebration of Wetland Day, reported that their wetland was at risk and needed assistance (Ministry of Natural Resources, 2004). The authorities reported that KKW was further degraded by developments efforts which were planned centrally.

Table 2 below shows the analysis of the science syllabus (NCDC, 2008) to determine the state of 
Table 2. Tested ecological concepts as presented in the science curriculum documents

\begin{tabular}{ll}
$\begin{array}{l}\text { Ecological concept } \\
\text { students were tested on }\end{array}$ & $\begin{array}{l}\text { Statement of the concept in science } \\
\text { syllabus }\end{array}$ \\
\hline $\begin{array}{l}\text { Biodiversity (as stated in } \\
\text { Form A syllabus) }\end{array}$ & $\begin{array}{l}\text { Explicitly stated as follows: Students } \\
\text { should: } \\
\text { - }\end{array}$ \\
& $\begin{array}{l}\text { Differentiate between classes of } \\
\text { arthropods using external structures }\end{array}$ \\
- Identify structural characteristics of \\
non-flowering plants. \\
- Identify live specimens using a key \\
diagram
\end{tabular}

Energy flow (as stated in Form A and B syllabus)

Ecosystem (as stated in Form B syllabus)
Explicitly stated as follows: Students should:

- Construct food chains and webs.

- Describe the use of food chains and webs.

- Explain interrelationship between the eaten and eater organisms.

- Describe how the food chains and webs may be disturbed and the consequences of the disturbance.

Explicitly stated as follows: Students should be able to:

- Describe ecosystem.

- Describe relationships shown by organisms in land and aquatic habitats with ecosystem.
Relevance of the concept to KWW

Almost all the arthropods and non-flowering plants stated in the syllabus are found in KKW.

Students can see birds eating frogs or fish from KKW as examples of food chains and webs.

Students could see the consequences of disturbances made on KKW.

KKW is a typical example of an ecosystem.

Students can discover the relationships of organisms with one another and their abiotic/ non-living environment. ecological concepts that students should know, and their relevance to a wetland ecosystem.

\section{Students' Conceptions of Key Biophysical Concepts}

Below are the findings on students' conceptions of key ecological concepts in relation to KKW ecosystem.

\section{Students' Knowledge on Wetland Animal Diversity}

When asked to name and describe features of a typical wetland animal, crab, 27 out of 31 (87\%) students, were able to name a crab. Nineteen students of the $31(61 \%)$ correctly classified a crab as an invertebrate; 12 (39\%) did not attempt to label the crab. Of those who labeled the crab none of them got the labels correct except one student who labeled one structure in the local language Sesotho as 'manaka', which could correctly be translated to mean antennae, but could also mean 'horns'. They were not able to label claws (Label 1), Antennae (Label 2), and Cephalothorax (Label 4). Two students $(6 \%)$ correctly gave the general characteristic structure of crustaceans: thorax, abdomen and head, in response to a question that asked them to name characteristics of crustaceans.

Students were further tested on their knowledge of five birds they thought were found in KKW. All students attempted the question, but less than half of the students, 13 (41\%), mentioned less than five birds. Sixteen students (52\%) mentioned five birds of which 13 (42\%) mentioned all five birds that can possibly be found in the wetland and five students listed other birds that could not exist in the wetland, namely a chicken and an ostrich. The latter does not exist in the wild in Lesotho. Table 3 below shows number of birds mentioned by students that could be found at KKW.

The six most frequently mentioned birds were: Leholosiane (Cattle egret), 'Letata' (Duck), 'Leeba' (Dove), Thaha (Bishop) and Kokolofitoe (Heron). These birds are also listed by the National Environmental Secretariat (2000), as part of Lesotho biodiversity.

Students were asked to name the wetlands birds in both their mother tongue, Sesotho, and in English, and most of them new the birds in their mother tongue. Seventeen students (55\%) specifically stated 
Table 3. Number of birds mentioned to occur at KKW

\begin{tabular}{lllllll}
\hline & \multicolumn{6}{c}{ Number of birds that students mentioned as occurring in the wetland } \\
\hline & 1 & 2 & 3 & 4 & $5^{*}$ & Total \\
\hline $\begin{array}{l}\text { Number } \\
\text { students }\end{array}$ & 2 & 1 & 3 & 9 & $16(13)$ & 31 \\
Percentages & $6 \%$ & $3 \%$ & $10 \%$ & $29 \%$ & $52 \%$ & $100 \%$ \\
\hline
\end{tabular}

*In parenthesis is reflected the number of students who mentioned all five correct wetland birds.

Table 4. Number of plants mentioned to ought to be found at KKW

Number of plants mentioned

\begin{tabular}{cccccccc}
\hline & 0 & 1 & 2 & 3 & 4 & $5^{*}$ & Total \\
\hline $\begin{array}{c}\text { Number of } \\
\text { students }\end{array}$ & 2 & 4 & 7 & 4 & 6 & $8(0)$ & 31 \\
Percentages & $6 \%$ & $13 \%$ & $23 \%$ & $13 \%$ & $19 \%$ & $26 \%$ & 100
\end{tabular}

*In parenthesis is reflected number of all five correct responses.

that they did not know common English names of the birds they listed, and none of them knew the common English names of all of the birds they mentioned.

\section{Students' Knowledge on Wetland Plants Diversity}

One test item required students to name a fern presented pictorially in the questionnaire, and to give any two characteristics of the plant. Only six students (19\%) were able to name a fern and 20 specifically stated that they did not know a fern (65\%). Five students $(16 \%)$ named a fern as a 'conifer', 'setsoari', and 'algae'. When asked to mention two characteristics of a fern, nearly half of the students, 15 (48\%), stated that they did not know its characteristics. Only one student (3\%) gave a fern's specific characteristics that it bears spores and that it is found in damp areas (3\%); and another one (3\%) correctly stated that a fern does not bear flowers and does not have true stem.

Students were further tested on their knowledge of at least five plants that they thought were found in Koro-Koro wetland, and to name them in both Sesotho and English. None of the students correctly mentioned five plants that could possibly be found in Koro-Koro wetland. Only eight students (26\%) listed five plants, and none of them correctly mentioned all five wetland plants, in both Sesotho and English (See Table 4). Four students (13\%) mentioned a bird, instead of a plant.

The five most frequently mentioned plants found in the wetland were: Lehlaka (11), Leloli (11), Selae (9), Moseha (4) and Phate-ea-ngaka (3). Twentythree students (74\%) did not know common English names of the plants they listed. Three students mentioned Bolele (Spirogyra) as a plant.

\section{Students' Knowledge on Wetland Food Chains and} Decomposition

The students were presented with a diagram of a food chain that involved bacteria feeding on a dead kingfisher, then kingfisher feeding on the frog and frog feeding on plankton. Twenty-eight students $(90 \%)$ were able to identify plankton as a producer from the food chain. When asked which organism in the food chain receives most of the energy, 10 students (32\%) considered bacteria as receiving the most energy as it was the last organism in the food chain. Nine students (29\%) thought it was the frog and five students (16\%) mentioned kingfisher as receiving most of the energy. One student (3\%) correctly considered plankton as receiving most of the energy from the food chain even though the student could not explain why he chose plankton.

When asked what would happen to the number of kingfishers if the frogs died, three students (10\%) said they did not know; three students (10\%) said the number of kingfishers would increase; and seventeen students (54\%) said that kingfishers would decrease in number. Three students (10\%) answered that kingfishers would die and decrease. Five students (16\%) answered that the kingfishers would die.

When asked how the death of Kingfisher would affect the environment, seven students (23\%) said that they did not know; eleven students (36\%) said that the death of kingfishers would bring about pollution; four students (13\%) said the bacteria would die. One student (3\%) said the kingfishers would add nutrients to the soil. Two students (7\%) said that there would be more bacteria. One student (3\%) said that there would be more frogs eating plankton leading to its end of existence. One student 
(3\%) said that people would no longer get the kingfishers. One student (3\%) said the death of kingfishers would affect the environment in 'a good way', and did not elaborate. One student's (3\%) response was that there would be no decomposition and there would be no manure if kingfishers died. One student (3\%) stated that kingfishers would migrate because there would be no frogs.

Concerning the concept of decomposition, nine students (29\%) did not attempt the question which asked them to define a decomposer. Only one student (3\%) considered a decomposer as an organism; two (6\%) defined a decomposer as an animal. Four students (13\%) considered a decomposer as "something" and two students (6\%) as "chemicals"; seven students (23\%) considered decomposition as rotting and one student (3\%) used the word 'decay' to define decomposition. Three students (10\%) considered decomposers to act on dead organisms.

\section{Students' Knowledge of the Importance of Wetland in the Water Cycle}

One questionnaire item asked students to mention the "importance of wetland in the water cycle". Eleven students (35\%) did not attempt this question. Four students (13\%) described a wetland as water reservoir in the water cycle: they used the words like wetland 'conserve' (one student/3\%), 'keep' (2 students/6\%) and 'store' (one student/3\%) water. Seven students (23\%) considered wetland as helping in "evaporation of water" in the cycle. Nine students' (29\%) responses were irrelevant to the question.

\section{Students' Knowledge of the Importance of a Wetland}

When asked to explain one importance of significance of a wetland ecosystem, the students mentioned a wide of responses. Twenty-six students (84\%) attempted this question. More than half of the students considered the provision of water service as an importance of a wetland (See Table 5). This was followed by students (19\%) who viewed the significance of wetland as a habitat for animals, and a third frequent category of students (16\%) was those who considered a wetland important as a habitat for plants.

\section{Students' Knowledge on a Wetland Ecosystem}

To further assess students on their conception of an ecosystem, they were tested on whether they considered a wetland an ecosystem or not and to give a reason for their answer (See Table 6). Nine out of 31 students (29\%) did not know the answer. Twentytwo students (71\%) considered a wetland an ecosystem but six of them (19\%) did not explain why they considered it an ecosystem; the other 16 (52\%), gave a variety of scientific and socio-economic reasons. Many of the students (33\%), however, considered a wetland an ecosystem because it was a habitat of some type.

\section{Students' Knowledge on the Importance of Water in the Wetland}

Students were specifically asked to mention the importance of water in a wetland ecosystem. Ten students (32\%) did not attempt the question on the importance in an ecosystem. Twelve students (38\%), however, gave responses that showed ecological importance of water: three (10\%) stated that water is used as a habitat or home for organisms; eight students (26\%), mentioned that plants and animals need the water to photosynthesize, grow and reproduce; and one of the students $(3 \%)$ gave a slightly elaborate scientific response that from the wetland plants grow so that in turn they absorb carbon dioxide from the atmosphere. Nine students (30\%) gave socio-economic reasons that water is used for domestic purposes like cooking, washing and irrigation.

\section{DISCUSSION}

The students' knowledge of ecological concepts is a reflection of their knowledge of the 'state' of environment in terms of the DPSIR framework. Fortuin et al. (2011) consider 'state' as a domain of DPSIR concerned with 'environmental quality'. According to Bradley and Yee (2015, p.12) the 'state' of environment concerns, "state of the natural and built environment (e.g., the quantity and quality of physical, chemical, and biological components), and human systems (e.g., population level and individual attributes)". They further argued that the 'state' of environment involves a dynamic interaction of the biotic, abiotic and human (Bradly \& Yee, 2015). The discussion below focuses on the students' knowledge of wetland biodiversity, wetland energy flow and wetland ecosystem as well as its importance.

\section{Students' Knowledge of Wetland Biodiversity}

The science syllabus requires students to know diversity of organisms in their local environment (NCDC, 2008). Students are also expected to be more scientifically detailed and differentiate between classes of arthropods using external structures (NCDC, 2008). The majority of students in this study (87\%) could recognize and name a crab; a crab is a common arthropod found in local wetlands and is also in Grade 8 science textbook. Most of the students (61\%) could further classify the animal scientifically. However, none of the students were able to able to label the animal. Their inability to describe the crab, in terms of its anatomy, could be attributed to their 
Table 5. Students views on the importance of the wetland ecosystem

\begin{tabular}{lcc}
\hline Emerging Importance & $\begin{array}{c}\text { Frequency } \\
\text { (Percentage) }\end{array}$ & Frequency* \\
\hline Habitat for animals & $19 \%$ & 6 \\
Habitat for plants & $16 \%$ & 5 \\
Habitat for organisms & $6 \%$ & 2 \\
Food chain & $3 \%$ & 1 \\
Photosynthesis & $3 \%$ & 1 \\
Stops soil erosion & $3 \%$ & 1 \\
Water & $58 \%$ & 18 \\
Grazing land & $3 \%$ & 1 \\
Students who did not attempt & $16 \%$ & 5
\end{tabular}

${ }^{*}$ The number of students does not add to 31 and $100 \%$ as each student was expected to give at least two importance.

Table 6. How students understand a wetland ecosystem

Reason why students considered a $\quad$ Number of students
wetland an ecosystem

\begin{tabular}{lcc} 
Habitat for organisms & 3 & $10 \%$ \\
Habitat for plants & 2 & $6.5 \%$ \\
Habitat for animals & 3 & $10 \%$ \\
Habitat for animals and plants & 2 & $6.5 \%$ \\
Biological environment & 1 & $3 \%$ \\
A place that attract tourists & 1 & $3 \%$ \\
Economically important & 2 & $6 \%$ \\
Important to humankind & 2 & $6 \%$ \\
$\begin{array}{l}\text { Invalid (not ecologically applied) } \\
\text { reasons }\end{array}$ & 1 & $3 \%$ \\
No reasons & 5 & \\
Students who did not know the & 9 & $16 \%$ \\
answer & & $29 \%$ \\
Total & 31 & 100 \\
\hline
\end{tabular}

limited familiarity with the organism in the natural environment (Helldén \& Helldén, 2008).

Birds are the most diverse species among vertebrates (National Environment Secretariat, 2000), and the largest animals found in KKW wetland ecosystem. About half of the students (52\%) were able to name five birds found in KKW. Three of the students' six most frequently mentioned birds are fauna that the National Environment Secretariat (2000) recognizes as typical to wetlands and rivers in Lesotho (See Table 7).

The students named the birds better in their home language, which suggests that they learned more about the birds in their home environment, rather than at school where the medium of instruction is English. This cultural knowledge is clearly an important component of students' understanding of KKW biodiversity, and drawing on Helldén \& Helldén,
(2008), Lotz-Sisitka (2015) argues that teachers should consider the culture of students when dealing with environmental issues. This cultural knowledge can be valorized for conservation, in line with DPSIR. Drawing on this framework, students' 'response' to any adverse 'impact' on birds, could be engendered by linking their local knowledge on birds with an economic benefit such as ecotourism and scientific knowledge on food chains; this would create a basis for their meaningful and purposeful 'response' to mitigate any negative 'impacts' on birds.

In relation to the students' knowledge of wetland plant diversity, only $19 \%$ of the students' knew the fern; and $65 \%$ of the students specifically noted that they did not know a fern. Furthermore, only two students $(6 \%)$ gave acceptable scientific characteristics of a fern. A further students' limited scientific knowledge of plant is reflected in the three 
Table 7. Students' mentioned wetlands birds

\begin{tabular}{|c|c|c|}
\hline $\begin{array}{l}\text { STUDENTS' MENTIONED } \\
\text { WETLAND BIRDS }\end{array}$ & $\begin{array}{l}\text { OCCURRENCE } \\
(\text { NES,2000: } 24)\end{array}$ & STATUS OF OCCURRENCE (NES,2000: 43-50)* \\
\hline Leholosiane (Cattle Egret) & Not mentioned & Abundant \\
\hline Letata (Duck) & Mentioned as typical wetland bird & $\begin{array}{l}\text { Seven species of ducks mentioned: three } \\
\text { Uncommon, two Rare, and two Common. }\end{array}$ \\
\hline Leeba (Dove) & Not mentioned & $\begin{array}{l}\text { Four dove species mentioned: One Uncommon, } \\
\text { one Common and two Abandoned. } \\
\text { Abandoned }\end{array}$ \\
\hline Thaha (Bishop) & Mentioned as typical wetland bird & Common \\
\hline Kokolofitoe (Grey Heron) & Mentioned as typical wetland bird & \\
\hline
\end{tabular}

Table 8. Students' mentioned wetlands plants

\begin{tabular}{ll}
\hline STUDENTS MENTIONED WETLAND BIRDS & OCCURRENCE NATIONALLY (NES,2000: 24) \\
\hline Lehlaka (Common Reed) & Mentioned as typical wetland grass species \\
Leloli & Not mentioned \\
Selae & Not mentioned \\
Moseha & Not mentioned \\
Phate-ea-ngaka & Not mentioned
\end{tabular}

students' mention of Spirogyra (Bolele) as a plant, possibly due to its green colour and ability to photosynthesize. Spirogyra belongs to a different taxonomic group, Protista Kingdom. A few students were able to mention plants normally found in wetland ecosystem, and none of them could correctly mention any five plants found in the wetland. It appears that the students' five most frequently mentioned plants were all of some economic importance (See Table 8) : Lehlaka (11) is a thatching reed and used for house construction in communities; Leloli (11) is a wetland plant used for making baskets and table-mats (sethebe); Selae (9) is an evergreen vegetable that grows in wetlands and can be available all year round; Moseha (4) is a wetland plant that is used to make a variety of materials such as brooms, sun hats, floor mats, baskets and rope; and Phate-ea-ngaka (3), a common medicinal plant, but not typically found in wetlands. Students with this cultural knowledge of the plants, could easily conceptualize the 'drivers' and the 'pressure' on the wetland flora, emanating from the communities' economic activities.

In general, students' knowledge of wetland animal diversity is better than their knowledge of wetland plant diversity, which could in part be attributed to 'plant blindness' (Yorek et al., 2008). As part of what Wandersee \& Schussler (1999) as cited by Yorek et al. (2008) coined 'plant blindness', they showed that only about $7 \%$ of 274 urban students who participated in their study in the US expressed scientific interest in plants. Many secondary school learners tend to have 'plant blindness' (Yorek et al., 2008), which characterized by, among others, the idea of thinking plants as just the backdrops for animal life and failing to see or notice the plants in the environment. This could be caused by students' lack of interaction with plants at schools and at home. It can be argued that the students can easily appreciate any adverse 'impacts' on wetland biodiversity, when 
they are familiar with its components, and its scientific and economic value. Thus, the loss of the once teeming wetland life (Ministry of Natural resources, 2004; Tlhakola, 2017) could be attributed to people's lack of knowledge and disconnection with it.

\section{Students' Knowledge of Energy Flow and}

\section{Decomposition in a Wetland Ecosystem}

The two key concepts used to test students' knowledge of wetland energy flow were the 'food chains' and 'decomposition'. The majority of students were able to identify a producer $(90 \%)$ from a given food chain, but they could not entirely explain energy flow in that they did not know that a producer is the organism that receives most of the energy from the sun, in a food chain. Only one student (3\%) correctly identified an organism (plankton) which receives most of the energy from the sun, but he could not explain why. Many students (32\%) erroneously considered the last organism in the food chain (bacteria) as receiving most of the energy and could not even say why. This conception of energy as increasing from the bottom to the top of the pyramid parallels Toman (2018) findings in a similar study, and could in part be attributed to the students conceptualization of a food chain as prey-predator relationship rather than energy flow process (Minshew et al., 2017 and Yorek et al., 2010). Just about half of the students were aware that if an organism dies, the population of the other organisms linked to it in a food chain would be affected: 54\% explained that a Kingfisher population would decrease if frogs die and a few $(10 \%)$ said it would increase. Several students (36\%) seemed to be oblivious of the energy flow concept, by explaining that kingfishers would perish due to 'environmental pollution', should the frogs die. The biotic interconnectedness of organisms is key to the 'state' of environment (Bradley \& Yee, 2015), and the students' comprehension of this dynamic interaction creates a basis for their sound conceptualization of the consequences of potential adverse 'impact' on an ecosystem.

The concept of decomposition in food webs is important in that it drives most natural cycles (e.g. carbon cycle). Yet the students' knowledge on decomposition was generally low, as $30 \%$ of them specifically stated that they did not know a decomposer; and only 3\% of them considered a decomposer an organism. Some described decomposition as merely rotting (23\%). Cetin (2007) similarly found that minority of students relate bacteria to the breakdown of organic matter; and Schizas et al. (2013) further established that students tend to relate decomposition dead organisms, and not to organic matter.

\section{Students' Knowledge of a Wetland Ecosystem and its Importance}

In terms of the DPSIR model, conceptualization of a wetland as an ecosystem would constitute a sound scientific understanding of the 'state' of environment. Student should be able to read the interwoven relationships between biotic and abiotic environment (Mitchell, 2009). According to the UN Convention on Biological Diversity:

\section{'An ecosystem is a functional unit comprising all the organisms in a particular place interacting with one another and with their environment, and interconnected by ongoing flows of energy and a cycling of materials.'(Matthews, 2013, p.1).}

The students were expected to at least define an ecosystem in accordance with the prescribed science textbook (used at Form B level), as a "relationship of organisms and their interaction with non-living environment". While the majority of students (71\%) were aware that a wetland is an ecosystem, they could not give a scientifically sound explanation why they considered a wetland an ecosystem. The highest ratio of the students (33\%) understood an ecosystem as a habitat (e.g. "Place where organisms live") and were silent about the complex interrelationships of the biotic and abiotic components. Jordan et al. (2009) also found that $75 \%$ of the students defined ecosystem as a place where an organism lives and that only $22 \%$ of them could define ecosystem in terms of its biophysical connections and interactions. From a DPSIR perspective, a student who holds a parochial conception of an ecosystem, that reduces an ecosystem to a habitat, may not fully conceptualize the consequences of adverse 'impacts' on an ecosystem and to envision appropriate mitigation 'responses'.

The students' knowledge of the ecological importance of water and the concept of water cycle, both of which are not explicitly stated in the science syllabus, is essential to their sound understanding of the 'state' of the environment. According to the JC syllabus, water content is treated in Grade 10, under the topic 'Chemistry of water'. The highest ratio of students (32\%) said they did not know the importance of water in an ecosystem; and many of those who attempted the question, mentioned ecological importance of water, and a few others its economic importance. One would have expected that students' knowledge on water to be high as they are taught about uses of water in JC science, yet only $29 \%$ could articulate the economic significance of water. 
Such socio-economic knowledge is essential to students' value of wetland water, and their avoidance of any adverse 'pressure' and 'impact' on it.

The water cycle is an essential abiotic part of a wetland ecosystem. Yet many students (35\%) did not know the importance of wetlands in the water cycle. While water cycle is not specifically part of the JC science syllabus, it is taught in agriculture subject that the study group also took. The few students (36\%) who knew that wetlands are important in the water cycle alluded to the function of wetlands in helping in evaporation of water to form clouds and as water reservoirs.

The discussion above shows some gaps in the students' knowledge of the identified key concepts associated with KKW ecosystem, which reflects possible limitations in their conceptualization of an ecosystem holistically, in terms of the DPSIR framework.

\section{CONCLUSION}

The study set out to investigate Grade 11 students' understanding of the ecological concepts in association with Koro-Koro Wetland. In general, the students' knowledge of the 'state' of a wetland fauna was relatively better that than of flora. Birds were better known to the students, and several of those that they identified were of national significance (NES, 2000). Their flora knowledge seemed to be of species that had some cultural economic importance. However, they demonstrated limitations in providing scientific descriptions of plants and animals. Failure to describe an organism is as a result of students not being exposed to organisms in their real life experiences (Helldén \& Helldén, 2008). Furthermore, many students did not understand the concept of energy flow in a wetlands ecosystem, and only a small number (3\%) knew that there is a lot of energy in producers than in any other organism in a food chain. All students could not fully define a decomposer, and decomposition could not be comprehended as a process of bacterial (and fungal) break down of organic material. Thus students could not appreciate an important ecological process that drives the recycling of organic materials and energy in an ecosystem. The concept of ecosystem itself was not fully comprehend, as most students (71\%) who considered a wetland an ecosystem, conceptualized it as a habitat, rather than a dynamic interaction of biotic and abiotic factors. These conceptual limitations of ecological concepts, reflect a limited conceptualization of wetland ecosystem 'holistically, in terms of the DPSIR framework. Thus, the study shows that many young people could be interacting with their water sources in non-scientific ways, with little appreciation of the complexity and fragile nature of their wetland water sources.

The underperformance of Lesotho secondary students in ecology (ECOL, 2013; ECOL, 2017), as well as the conceptual limitations identified in this study, corroborates Molapo et al. (2014) case study findings that secondary students, in this context, have a rather narrow understanding of environment, with limited knowledge of their biophysical environment, possibly due to teacher-centered pegadogy. It is therefore recommended that a collective effort be undertaken by government, teachers training institutes and curriculum development institutions to develop a holistic science curriculum that is guided by the DPSIR framework, and that develops contextualized teaching competences for engaging students scientifically with their immediate biophysical environment.

The study, however, has limitations in that it is based on a single case that involves one class of students, situated in a peri-urban setting, and its findings therefore not be generalizable to other contexts. Future research, could explore the transferability of the findings to similar contexts, as well as carry out surveys to determine the students' conceptions of the wetland ecological concepts, in schools located in the various geographical and socioeconomic regions of the country.

\section{REFERENCES}

Adekola, O., \& Mitchell, G. (2011). The Niger Delta wetlands: Threats to ecosystem services, their importance to dependent communities and possible management measures. International Journal of Biodiversity Science, Ecosystem Services \& Management, 7(1), 50-68. https://doi.org/10.1080/21513732.2011.603138

Ambrose, D. (1998). Birds including annotated species checklist. Institute of Education; National University of Lesotho.

Arkwright, A. B. (2014). Fourth and eighth grade student's conception of energy flow through ecosystem [Doctoral Dissertation, University of Kentucky]. University of Kentucky Institutions Repository. https://uknowledge.uky.edu/edsc_etds/3

Barbier, E. B., Acreman, M. C., \& Knowler, D. (1997). Economic valuation of wetlands: A guide for policy makers and planners. Ramsar Convention Bureau.

Barrow, C. J. (1995). Developing the environment: problems and management. Longman Group Limited.

Belle, A. J., \& Collins, N., \& Jordan, A. (2018). Managing wetlands for disaster risk reduction. A case study of Eastern Free State, South Africa. Jamba Journal of Disaster risk studies, 10(1). 
https://jamba.org.za/index.php/jamba/article/vie $\mathrm{w} / 400 / 829$.

Bradley, P., \& Yee, S. (2015). Using the DPSIR Framework to Develop a Conceptual Model: Technical Support Document. Atlantic Ecology Division, Narragansett, RI. EPA/600/R-15/154. US Environmental Protection Agency, Office of Research and Development.

Cetin, G. (2007). English and Turkish pupils' understanding of decomposition. Asia Pacific Forum on Science Learning and Teaching, 8(2), Article 5.

Cohen, L., Manion, L., \& Morrison K. (2007). Research methods in education, Sixth Edition. Routledge, Taylor and Francis Group.

Department of Environment (2009). Environmental Education Strategy towards 2014. A strategic plan for Education for Sustainable Development in Lesotho. Ministry of Tourism and Environment.

Department of Environment (2009). Lesotho Fourth National Report on Implementation of Convection on Biological Diversity. Ministry of Tourism and Environment.

Examination Council of Lesotho [ECOL] (2013). JC Science Examiner's Report. Ministry of Education and Training.

Examination Council of Lesotho [ECOL] (2017). JC Science Examiner's Report. Ministry of Education and Training.

Farquhar, J., \& Michels, N. (2016). Triangulation without tears. In M. Groza \& C. Ragland (Eds.), Marketing challenges in a turbulent business environment. Developments in marketing science: Proceedings of the academy of marketing science. Springer, Cham. https://doi.org/10.1007/978-3319-19428-8_86

Fortuin, K. P. J., Van Koppen C. S. A., \& Leemans, R. (2011). The value of conceptual models in coping with complexity and interdisciplinary in environmental sciences. Bioscience, 60(10), 802814. https://doi.org/10.1525/bio.2011.61.10.10

Helldén, G., \& Helldén, S. (2008). Students' early experiences of biodiversity and education for a sustainable future. Nordina, 4(2), 123-131.

Honorene, J. (2017). Understanding the role of triangulation in research. Scholarly Research Journal for Interdisciplinary Studies, 4(31), 91-95.

Jordan, R., Gray, S. \& Demeter, M. (2009). An assessment of students' understanding of ecosystem concepts: Conflating Ecological systems and cycles. Applied Environmental Education and Communication, 8, 40-48.

Kristensen, P. (2004). The DPSIR Framework. National Environmental Research Institute, Denmark

Levin, P. S., Breslow, S. J., Harvey, C. J., Norman, K. C, Poe, M. R., Williams, G. D., \& Plummer, M. L. (2016). Conceptualization of social ecological systems of the California current: An examination of interdisciplinary science supporting ecosystembased management. Coastal Management, 44(5),
397-408.

https://doi.org/10.1080/08920753.2016.1208036

Lotz-Sisitka, H. (2005). Situated culture and new learning theory: Emerging perspectives in environmental education research. Southern African Journal of Environmental Education, 22, 510.

Matthews, G. V. T. (2013). The Ramsar convection on wetlands: Its history and development. Ramsar.

Merriam, S. B. (1998). Qualitative research and case study applications in education. Jossey-Bass Publishers

Menzel, S., \& Bögeholz, S. (2009). The loss of biodiversity as a challenge for sustainable development: How do pupils in Chile and Germany perceive resource dilemmas? Research in Science Education, 39, 429-447.

Mills, J., Harrison, H., Franklin, R., \& Birks, M. (2017). Case study research: Foundations and methodological orientations. Forum Qualitative Sozialforschung / Forum: Qualitative Social Research, 18(1), 1-17. https:// doi.org/10.17169/fqs-18.1.2655

Ministry of Forestry, Range and Soil Conservation (2015). National Action Programme. Report to the United Nations Convention to Combat Desertification. Government of Lesotho. Government of Lesotho Printers.

Ministry of Natural Resources. (2004, February). Report on the Commemoration of the World Wetlands Day in Lesotho. Government of Lesotho.

Minshew, L. M., Barber-Lester, K. J., Derry, S. J., \& Anderson, J. L. (2017). Leveraging students' knowledge to adapt science curricula to local context. Educational Technology and Society, 20(4), 205-218.

Mitchell, D. B. (2009). A philosophical analysis of David Orr's theory of ecological literacy: Biophillia, ecojustice and moral education in middle school learning communities [Doctoral Thesis, University of Georgia]. The University of Georgia Press. https://getd.libs.uga.edu/pdfs/mitchell_debr a_b_200905_ma.pdf.

Mokuku, T., \& Taylor, J. (2015). Tlokoeng Valley community's conceptions of wetlands: Prospects for more sustainable water resources management. Journal of Education for Sustainable Development, 9(2), 196-212. https://doi.org/10.1177/0973408215588254

Molapo, L., Stears, M., \& Dempster, E. (2014). Does environment knowledge inform the everyday practices of senior secondary biology learners in Lesotho. Southern African Journal of Environmental Education, 30, 118-129.

National Curriculum Development Corporation (2008). JC Science Syllabus. Government of Lesotho Printers. 
National Environment Secretariat, (2000). Biological Diversity in Lesotho. Morija Printing Works.

Olsen, W. (2004). Triangulation in social research: Qualitative and quantitative methods can really be mixed. Auseway Press.

Rabiatul, A., \& Norizan, E. (2013). Ecological literacy among secondary school students. CoSMED 2013 5th Conference on Science and Mathematics Education 11-14 November 2013. FS8 RAMJ, Penang, Malaysia.

Russi, D., ten Brink, P., Farmer, A., Badura, T., Coates, D., Förster, J., Kumar, R., \& Davidson, N. (2013). The economics of ecosystems and biodiversity for water and wetlands. Institute for European Environmental Policy \& Ramsar Secretariat.

Schizas, D., Katrana, E., \& Stamou, G. (2013). Introducing network analysis into science Education: Methodological research examining secondary school students' understanding of decomposition. International Journal of Environmental \& Science Education, 8(1), 175-198.

Shepardson, D. P., Wee, B., Priddy, M., \& Schelleenberger, L. (2007). What is a watershed? Implications of student conceptions for environmental science education and the National Science Education Standards. Science Education, 91, 554-578. https://doi.org/10.1002/sce.20206

TEEB (2010). The economics of ecosystems and biodiversity ecological and economic foundations. Earthscan, London.

Tlhakola, K. D. (2017). Investigating useful local knowledge on loss of biodiversity at Ha Mokuoane and its implications for school curriculum. Research Report. National University of Lesotho.

Toman, U. (2018). An Investigation into the learning of ecological concepts. European Journal of Educational Research, 7(3), 631-638.

UNESCO \& UNFCCC (2016). Action for climate empowerment. Guidelines for accelerating solutions through education, training and public awareness. https://unfccc.int/files/cooperation_and_support/e ducation_and_outreach/application/pdf/action_for_ climate_empowerment_guidelines.pdf.

Wandersee, J. H., \& Schussler, E. E. (1999). Preventing plant blindness. The American Biology Teacher, 61(2). 82-86.

Weston, M. A., Tzaros, C. L. \& Antos, M. J. (2006). Awareness of wetlands and their conservation values among students at a primary school in Victoria, Australia. Ecological Management and Restoration, 7(3), 223-226.

Yamaguchi, K., \& Okada, K. (2018). Comparison among cognitive diagnostic models for the TIMSS2007 fourth grade mathematics assessment. PLOS ONE 13(2). e0188691. https://doi.org/10.1371/journal.pone.0188691

Yardimci, E., \& Kilic, G. (2010). Children's views of environment and environmental problems.

Elementary Education Online, 9(3), 1122-1136.
Yorek, N., Aydin, H., Ugulu, I., \& Dogan, Y. (2008). Investigation on students' perceptions of biodiversity. Natura Montenegrina, Podgorica, 7(3), 175-184.

Yorek, N., Sahin, M., Ugulu, I., \& Dogan, Y. (2010). A Qualitative investigation of students' understanding about ecosystem and its components. Natural Montenegrina, 9(3), 973-981. 